\title{
Erratum: Structural isomerism in gold nanoparticles revealed by $\mathrm{X}$-ray crystallography
}

Shubo Tian, Yi-Zhi Li, Man-Bo Li, Jinyun Yuan, Jinlong Yang, Zhikun Wu \& Rongchao Jin

Nature Communications 6:8667 doi: 10.1038/ncomms9667 (2015); Published 20 Oct 2015; Updated 17 Nov 2015

The original version of this Article contained an error in the spelling of isomerism in the title of the paper. This has now been corrected in both the PDF and HTML versions of the Article.

(c) (i) This work is licensed under a Creative Commons Attribution 4.0 International License. The images or other third party material in this article are included in the article's Creative Commons license, unless indicated otherwise in the credit line; if the material is not included under the Creative Commons license, users will need to obtain permission from the license holder to reproduce the material. To view a copy of this license, visit http://creativecommons.org/licenses/by/4.0/ 